\title{
English Language Anxiety and Its Effect on Students' Mathematics Achievement
}

\author{
Yazan Alghazo ${ }^{1} \&$ Hasan Al-Wadi ${ }^{1}$ \\ ${ }^{1}$ Bahrain Teachers College, University of Bahrain, Manama, Bahrain \\ Correspondence: Yazan Alghazo, Bahrain Teachers college, University of Bahrain, Manama, Bahrain.
}

Received: May 10, 2019

doi:10.5539/ies.v12n12p130
Accepted: September 2, $2019 \quad$ Online Published: November 29, 2019

URL: https://doi.org/10.5539/ies.v12n12p130

\begin{abstract}
Difficulties faced in learning a specific mathematical vocabulary are amplified through incomplete English knowledge among students who English Language Learners (ELLs). Therefore, the present study aims to investigate the relationship between English language anxiety and the mathematical achievement of EFL/ESL students who are using EMI. Mixed research method was employed to identify and understand this relationship between language anxiety and mathematics achievement in the math classroom. To collect quantitative data, a questionnaire was distributed to the students to measure their level of English language anxiety and mathematics achievement using their grades in their mathematics classes. The association between English language anxiety levels and ESL/EFL achievement in Mathematics was investigated through Pearson's correlation test. The results showed medium levels English language anxiety among the EFL/ESL students with a mean of (2.15) and a standard deviation of (0.73). The results indicated no statistical difference in means of English language anxiety that can be attributed to the program type or graduation year $(\alpha \leq 0.05)$. The study concluded that English language anxiety was neutral as majority of students become nervous, when the teacher asks them unexpected questions.
\end{abstract}

Keywords: communication, English language anxiety, EFL/ESL learners, mathematics achievement, English as medium of instruction

\section{Introduction}

\subsection{Introduction}

Anxiety is defined as an emotional and attitudinal fluctuation that people endure towards a specific object; such as second language acquisition (Mahmood \& Iqbal, 2010). It is an integral component of any learning environment and is essential in certain learning situations $(\mathrm{Na}, 2007)$. The curiosity of students towards a certain topic is considered to be a hidden form of anxiety and this is why students are asked to maintain a certain level of anxiety to keep interest and motivation in their studies, since different levels of anxiety can result in different effects on their learning processes (Mahmood \& Iqbal, 2010; Macintyre, 1995). In the EFL/ESL context, anxiety in using English as an EFL/ESL may lead to communication difficulties among students, who use the target language as their means of learning and communication with their teacher and peers. Consequently, these communication difficulties may result in adopting the norms and habits of an English-speaking learning environment and achieve the desired learning goals (Woodrow, 2006) as anxiety is reported to be one of the most influential emotional factors, involved in learning second language (Mahmood \& Iqbal, 2010)

As a result, The language, that is used to teach mathematical ideas, needs to be considered, especially when the language is not a mother tongue but a foreign or second language (Kim, 2002; Joen, 2002) or if the students have not achieved higher level of proficiency(Cuevas, 1984). The level of English anxiety among the students is important to be investigated, since many universities in non-English speaking countries are now implementing curricula that are entirely delivered using English as the main medium of instruction (EMI). However, many schools offer preparatory programs as remedial for students to improve their skills in the target language. Yet, the majority of students still suffer high anxiety levels during their English courses as well as other major courses that are taught in English, which include mathematics and physics courses (Yamashiro \& McLaughlin, 2001).

It is important to assess whether the language of the test instruments interferes with content knowledge and skills in a reliable and valid way. According to Abedi et al. (2006), continued accommodation is necessary for determining valid assessments of EFL/ESL students' language learning especially that it will help them learn as 
non-ELL peers. However, the performance of students is likely to differ between different types of language related accommodation, while learning mathematics.

Global universities have started using EMI in the majority of their courses. Accordingly, issues of anxiety might develop more among the students, especially when they are EFL/ESL. It has been shown that learning mathematics for EFL/ESL learners is complex as it is associated with the involvement of manipulating new concepts, new vocabulary, development of reasoning skills, and deductive processes (Rosa, 2015). The difficulties faced in learning a specific mathematical vocabulary are amplified through incomplete English knowledge among the ELL students. This urges to investigate and understand current strategies used in ELL mathematics education and form coherent picture of this process in order to control it and direct to the benefit of the EFL/ESL learners.

The implication for teachers knowing their students' learning styles provides insights to plan their lessons using these tools. Teaching English-language writing in a Saudi context creates specific challenges for teachers. The present study aims to investigate English anxiety levels among students, attending a four-year university in Saudi Arabia. The study has also investigated how the anxiety levels affect the achievement in mathematics courses among students. The study further investigated certain differences between students' performance on mathematics tests written in their native language (Arabic) and their second language (English). The research questions addressed in the present study are as follows;

1) Is there a significant correlation between English language anxiety levels and English language learners' achievement in mathematics?

2) Why English Language Learners face difficulties when they are taught mathematics in English?

\subsection{Literature Review}

The particular relationship between English language anxiety and mathematics achievement of EFL/ESL students have been focused in the literature. Therefore, the major emphasis placed by the present study focuses on investigating the effects of English language anxiety in achieving mathematics courses taught in the English language to the EFl/ESL learners. The majority of researchers have focused their attention on the association between foreign language anxiety and achievement in language courses (Liu, 2007; Awan et al., 2010; Bailey \& Heritage, 2014). Awan et al. (2010) conducted a study that included 149 participants, who were ELL undergraduate university students. The anxiety levels of the students were measured and compared with their achievements in college by using GPA in English courses as the primary indicator of achievement. The results concluded that there is a negative association between English anxiety and student achievement in English classes. The study also revealed that speaking English in front of others was among the significant causes for anxiety.

Woodrow (2006) conducted a study that included 275 students, enrolled in English for Academic Purpose (EAP) programs to investigate the relationship between English anxiety and students' achievement in EAP courses. The findings indicated that English anxiety was the highest predictor of achievement. Similarly, Gai and Yang (2010) studied the effects of English language anxiety on students' linguistic abilities and revealed that anxiety negatively affects students' linguistic achievement, especially their achievement in speaking English. Ewald (2007) asserted that anxiety significantly affects the language learning and achievement. There is a negative influence of increased level of anxiety on the language acquisition process. It is difficult for the learners to immerse themselves within an unfamiliar language setting. Therefore, communicative approach has introduced in teaching English language (Wu, 2010). The effectiveness of language learning depends on the language practice, which occurs in meaningful context, instead of isolated linguistic settings. The students are likely to face difficulty in learning real-life communicative English; although, the students are good at memorizing vocabulary and grammatical rules. The native teachers prefer the adoption of student-centred approach; whereas, the traditional teachers tend to find intense difficulties to adapt to innovative learning environment. The language learners are significantly affected by communication apprehension, negative evaluations, and test anxiety ( $\mathrm{Wu}, 2010)$. Foreign language anxiety is considered as a form of situation-specific foreign language anxiety refers to the anxiety of students learning English, while remaining in an environment that utilized their first language for everyday communication.

The effectiveness of language learning depends on the language practice, which occurs in meaningful context, instead of isolated linguistic settings. A study conducted by Otilia (2014) investigated current understanding of ELL regarding mathematics education. The results depicted that communication can be conducted efficiently if both the sender and the receiver agree upon their meaning, or the message in advance. Multiple meanings on a word in English act as a deterrent against registry formation and discursive practices. A study also showed that majority of the ELL is at disadvantage, while learning mathematical problems. Therefore, efficient pedagogical practices are needed to better prepare ELLs for academic success in mathematics (Edel, 2018). 
Hwang et al. (2017) conducted a study to evaluate the interaction of problem-based gaming and learning anxiety in language students' English learning performance and progressive behavioural patterns. A total of 77 students of ninth grade were enrolled in the study. In the following study, a problem-based English listening computer game was developed and its impact on the achievement of students was evaluated. The results of the study suggested that the gaming solution proved to be beneficial for the achievement of learning motivation and achievement among students. Also, the results suggested that the more was the level of anxiety of students, the more benefits students achieved.

Hung (2015) evaluated the impact of flipping classroom on the participation levels, academic performance and learning attitudes of English Language Learners (ELLs). The study adopted a Web Quest active learning strategy to incorporate the following attempt in the learning activity of students. Three formats/designs for flip teaching were developed to incorporate in the quasi-experimental design. Thus, positive results were obtained, and the learning outcomes, learning attitudes and learning motivation were also significantly impacted by the structured and semi-structured flip lessons.

Bailey and Heritage (2014) assessed the role of language learning progressions in improved assessment and instruction of English Language Learners (ELL). The issues related to the evaluation and development of language learning progressions were discussed in the study. The study involves the development of a new language learning progression along with the formative assessment initiative, primarily based on the explanation classification as reported by the students through a number of English language experiences. Moreover, it was concluded as how new progression can help in increasing the growth of students and the formative assessment of teachers who were practicing with K-12 students seeking to learn English.

Hong et al. (2015) evaluated the impact of homework motivation and worry anxiety on homework achievement in English and Mathematics. A total of 268 students were included in the study as the sample. The study suggested that the homework motivation was basically the motivation application, homework self-efficacy, task value, and homework worry anxiety among students. Thus, the results showed that, homework worry and efforts were both positively and negatively influenced by homework self-efficacy respectively. Moreover, homework worries and efforts in English and Mathematics were significantly and positively influenced by homework value. Furthermore, a prominent relation between homework value, homework effort and homework achievement were recorded in Mathematics. Thus, the relationship between self-efficacy, worry anxiety and achievement among students was found to be more significant in Mathematics homework as compared to English homework.

Chval et al. (2015) evaluated the impact of language while teaching mathematics to English Language Learners (ELL). One teacher teaching the students of class three was selected as the study sample. The teacher developed methods to facilitate ELL learners while teaching mathematics, by focusing on language. Results showed that professional development in language learning in mathematics is essential for teachers. Hence, to teach mathematics to ELLs, language development and planning is necessary for the attainment of competency and knowledge regarding the subject. The language learning among several regions and students of different ages is becoming more and more important due to the changing dynamics of academics and level of competition increasing day by day. Therefore, English Language Learners (EELs) must be given appropriate training and knowledge to help them in mathematics learning.

\section{Method}

\subsection{Study Design}

Collins et al. (2006) suggest that a mixed-methods approach can provide instrument validity and significance enhancement to the findings. This approach helps in the validation of results that are obtained from other methods. Moreover, it extensively focuses on the research questions to clarify unexpected findings and contradictions. Therefore, the study has utilized a mixed methods design to address the research questions and provide a more comprehensive understanding of the association between anxiety and mathematics achievement in classrooms.

\subsection{Participant (Subject) Characteristics}

The students were selected randomly from four mathematics classrooms, where the English was used as the main medium of instruction to deliver the course content. 213 students volunteered and completed the questionnaire.

\subsection{Data Collection}

The participants for the study were both male and female students $(\mathrm{N}=213)$, enrolled at a private university in Saudi Arabia, where all the instructions were delivered in English. Vast majority of students were from Saudi Arabia and spoke Arabic as their first language. Moreover, majority of them were either going through the English preparatory program or had recently completed the preparatory program and began taking courses at their 
respective colleges. A questionnaire was distributed to the students to measure their English Anxiety and their grades in their mathematics classes.

Table 1 has presented demographic characteristics of students in terms of gender, college level, program type, year graduation, completed Mathematics courses, country, and instructor.

Table 1. Demographic characteristics of respondents

\begin{tabular}{|c|c|c|c|}
\hline Variable & Category & Frequency & Percent \\
\hline \multirow{2}{*}{ Gender } & Male & 39 & 18.3 \\
\hline & Female & 174 & 81.7 \\
\hline \multirow{5}{*}{ College Level } & Prep Year & 76 & 35.7 \\
\hline & Freshman & 51 & 23.9 \\
\hline & Junior & 1 & .5 \\
\hline & Sophomore & 38 & 17.8 \\
\hline & Senior & 47 & 22.1 \\
\hline \multirow{2}{*}{ Program Type } & $\begin{array}{l}\text { Full time/Morning } \\
\text { Student }\end{array}$ & 189 & 88.7 \\
\hline & $\begin{array}{l}\text { Part time/ Evening } \\
\text { Student }\end{array}$ & 24 & 11.3 \\
\hline \multirow{2}{*}{ Year of Graduation } & 2012 \& before & 104 & 48.8 \\
\hline & After 2012 & 109 & 51.2 \\
\hline \multirow{10}{*}{ Completed Mathematics Courses } & 1 & 10 & 4.7 \\
\hline & 2 & 16 & 7.5 \\
\hline & 3 & 15 & 7.0 \\
\hline & 4 & 2 & 0.9 \\
\hline & 5 & 19 & 8.9 \\
\hline & 6 & 26 & 12.2 \\
\hline & 7 & 34 & 16.0 \\
\hline & 8 & 33 & 15.5 \\
\hline & 9 & 22 & 10.3 \\
\hline & 10 & 36 & 16.9 \\
\hline \multirow{3}{*}{$\begin{array}{l}\text { Have you lived in an English-speaking country for more than one year in your life after } \\
\text { the age of } 10 ?\end{array}$} & Yes & 55 & 25.8 \\
\hline & No & 158 & 74.2 \\
\hline & Native English Speaker & 74 & 34.7 \\
\hline Instructor & $\begin{array}{c}\text { Non-native English } \\
\text { Speaker }\end{array}$ & 139 & 65.3 \\
\hline
\end{tabular}

Qualitative data were collected through semi-structured interview questions. The participants were selected for the interview. The interview questions mainly aimed at exploring the reasons behindany difficulty students were having with their mathematics courses. To achieve this, four mathematics classrooms were randomly selected, where the lecture was being delivered in English. After quantitative data had been collected, 12 students were selected for interviews regarding their experiences in their mathematics classroom. The students were also asked about reasons for any difficulties they faced or are facing in their mathematics learning experiences in those classes. The collected data was analysed using SPSS (version 20.0).

\subsubsection{Instrumentation}

The instrument used was a 32-item, 4-point Likert scale designed to measure English Learning Anxiety. The English Learning Anxiety Scale (ELAS) (Lee, 2011) is a modified version of Foreign Language Anxiety Scale (FLCAS) that was developed by Horwitz et al. (1986). Although language anxiety is significantly higher in mainstream classes, the results deduced from ELAS tend to indicate levels of language anxiety in mainstream classes. The responses of ELAS mainly focus on anxiety in the mainstream. Therefore, the instrument measured language anxiety on three sub-scales; communication anxiety, test anxiety, and fear of negative evaluation. Lee (2011) conducted a pilot study to measure reliability coefficients for all the sub-categories of the instrument. The reliability coefficients of $.82, .77, .78$, and .86 for all three subscales and the overall anxiety scale were reported, consecutively. A panel, consisting of three professors of education, reviewed the items for their accuracy to be used 
with the current sample of participants. The researchers requested students' permission to collect their test grades from their mathematics courses instructors to gather data for the mathematics achievement variable. Students received average grades on all course tests (Test one, test two, final exam) that were collected from all participating instructors of mathematics courses. 2.3.2 Measures and Covariates

Include in the Method section information that provides definitions of all primary and secondary outcome measures and covariates, including measures collected but not included in this report. Describe the methods used to collect data (e.g., written questionnaires, interviews, observations) as well as methods used to enhance the quality of the measurements (e.g., the training and reliability of assessors or the use of multiple observations). Provide information on instruments used, including their psychometric and biometric properties and evidence of cultural validity.

\section{Results}

There is a long-standing tradition of activity of translation that is practiced widely. The phenomena of translation have become important due to expansion of international knowledge. Thereby, the focus of translation studies has been, recently, shifted away from linguistics to forms of cultural studies. The standard deviations, ranks, and the mean levels of English language anxiety were calculated to investigate the level of English language anxiety among the students (Table 2). The levels of English language anxiety were medium, with a mean of (2.15) and a standard deviation of (0.73). The highest was item (17) "I become nervous when the teacher asks me unexpected questions and I have to answer them" with a mean of (2.44) and a standard deviation of (1.02). And the item (14) "I'm afraid that I might make mistakes in front of the class when taking an oral test (presentation)" came in the last rank with a mean of (1.88) and a standard deviation of (1.00). 
Table 2. Means, standard deviations, ranks and the means of english language anxiety

\begin{tabular}{|c|c|c|c|c|c|}
\hline Ranks & No. & Item & Mean & SD & $\begin{array}{l}\text { Mean } \\
\text { level }\end{array}$ \\
\hline 1 & 17 & $\begin{array}{l}\text { I become nervous when the teacher asks me unexpected questions and I have to answer them } \\
\text { verbally }\end{array}$ & 2.44 & 1.02 & Medium \\
\hline 2 & 10 & I'm afraid that there are spelling or grammar mistakes when writing sentences & 2.40 & 1.02 & Medium \\
\hline 3 & 13 & English listening comprehension tests. & 2.38 & 1.12 & Medium \\
\hline 4 & 1 & I feel that the other students speak English better than I do & 2.38 & 0.96 & Medium \\
\hline 5 & 3 & I get nervous when I don't understand the words the native English speakers say & 2.36 & 1.04 & Medium \\
\hline 6 & 21 & $\begin{array}{l}\text { I worry about making mistakes due to limited vocabulary and incorrect word usage when testing } \\
\text { in English translation or writing }\end{array}$ & 2.28 & 1.00 & Medium \\
\hline 7 & 16 & $\begin{array}{l}\text { I'm afraid that I can't complete all the questions within the specified time due to my slow } \\
\text { reading speed }\end{array}$ & 2.26 & 1.03 & Medium \\
\hline 8 & 7 & I get nervous when the teacher calls on me to do the text summary & 2.25 & 1.03 & Medium \\
\hline 9 & 18 & I get panicky when there are many words, I don't know on English tests & 2.25 & 0.98 & Medium \\
\hline 10 & 20 & I worry about my writing speed too slow when testing English translation or writing & 2.24 & 1.01 & Medium \\
\hline 11 & 6 & I'm afraid to make mistakes when the teacher asks me to answer questions in English & 2.23 & 1.11 & Medium \\
\hline 12 & 2 & It frightens me when I don't understand what the teacher is saying in the English class & 2.21 & 0.99 & Medium \\
\hline 13 & 22 & $\begin{array}{l}\text { I worry about the insufficient use of sentence patterns when testing in English translation or } \\
\text { writing }\end{array}$ & 2.21 & 0.95 & Medium \\
\hline 14 & 23 & $\begin{array}{l}\text { I worry about the insufficient use of sentence patterns when testing in English translation or } \\
\text { writing }\end{array}$ & 2.20 & 1.00 & Medium \\
\hline 15 & 19 & I get nervous when I don't understand grammar or sentence structures on tests & 2.19 & 1.04 & Medium \\
\hline 16 & 9 & I get nervous when I have to write the reflections after reading & 2.13 & 0.99 & Medium \\
\hline 17 & 30 & $\begin{array}{l}\text { I worry about an English teacher who might have negative feelings about me due to my bad } \\
\text { performance on English listening comprehension exercises }\end{array}$ & 2.11 & 1.02 & Medium \\
\hline 18 & 25 & I have no confidence in my English listening comprehension & 2.10 & 1.02 & Medium \\
\hline 19 & 12 & I get nervous about possibly not "keeping up" or receiving poor scores when taking & 2.08 & 0.88 & Low \\
\hline 20 & 4 & I worry that my English listening ability is not good & 2.07 & 0.95 & Low \\
\hline 21 & 5 & I don't dare to speak English with other students & 2.06 & 1.00 & Low \\
\hline 22 & 31 & I feel my heart beating up when I know that I am going to be called on in English class & 2.05 & 1.04 & Low \\
\hline 23 & 26 & I don't know what I'm talking about when I feel nervous in English class & 2.02 & 1.05 & Low \\
\hline 24 & 11 & I get nervous when taking English listening comprehension tests & 2.02 & 0.91 & Low \\
\hline 25 & 15 & I get nervous when the teacher asks questions in English class & 2.00 & 1.01 & Low \\
\hline 26 & 29 & $\begin{array}{l}\text { I'm afraid to be criticized or scorned by peers during team discussion because of my poor } \\
\text { English }\end{array}$ & 1.99 & 1.00 & Low \\
\hline 27 & 8 & I worry that I'm unable to communicate with others because of my low English proficiency & 1.97 & 1.02 & Low \\
\hline 28 & 27 & I am afraid that the other students will laugh at me when doing an English presentation & 1.97 & 1.01 & Low \\
\hline 29 & 28 & $\begin{array}{l}\text { I'm afraid that my broken English pronunciation would cause jokes when I want to bring up } \\
\text { questions }\end{array}$ & 1.92 & 0.94 & Low \\
\hline 30 & 24 & $\begin{array}{l}\text { I get nervous when the English teacher asks me questions for which I haven't prepared in } \\
\text { advanced }\end{array}$ & 1.91 & 0.97 & Low \\
\hline 31 & 14 & I'm afraid that I might make mistakes in front of the class when taking an oral test (presentation) & 1.88 & 1.00 & Low \\
\hline Anxiety & & & 2.15 & 0.73 & Medium \\
\hline
\end{tabular}

Table 3 presented the mean, standard deviation and t-test for the differences in means of English language anxiety attributed to gender. There is significant difference at $(\alpha=0.05)$ in means of English language anxiety attributed to gender, because p-value less than $(0.05)$ is in the favour of female.

Table 3. Mean, standard deviation and t-test for the differences in means of English language anxiety attributed to gender

\begin{tabular}{ccccccc}
\hline Gender & $\mathrm{N}$ & mean & $\mathrm{SD}$ & $\mathrm{t}$-value & $\mathrm{df}$ & Sig. \\
\hline Male & 39 & 1.81 & 0.69 & \multirow{2}{*}{-3.27} & \multirow{2}{*}{211} & $0.001^{*}$ \\
Female & 174 & 2.22 & 0.73 & & & \\
\hline
\end{tabular}


RQ2: Is there significant association between English language anxiety levels and English language learners' achievement in mathematics?

Table 4 shows the means and standard deviations for the English language anxiety among the students at college level to investigate statistical difference among the obtained results. There were noticeable differences in the means of the English language anxiety calculated according to college levels.

Table 4. Mean and standard deviation for the English language anxiety according to the level of college

\begin{tabular}{lccc}
\hline College Level & $\mathrm{N}$ & Mean & $\mathrm{SD}$ \\
\hline Prep Year & 76 & 2.15 & 0.71 \\
Freshman & 51 & 2.12 & 0.70 \\
Junior & 1 & 3.26 & - \\
Sophomore & 38 & 2.07 & 0.81 \\
Senior & 47 & 2.21 & 0.76 \\
Total & 213 & 2.15 & 0.73 \\
\hline
\end{tabular}

One-way ANOVA test was applied to find out, if these differences were significant. Table 5 has shown that there are no significant differences at $(\alpha=0.05)$ in the means of the English language anxiety according to college levels with $\mathrm{F}=(0.79)$ at $(0.0 .53)$ level of significance. In order to find significant statistical differences in means of English language anxiety attributed to program type independent t-test has been conducted. The results show that there is no statistical difference at $(\alpha \leq 0.05)$ in means of English language anxiety attributed to program type and graduation year, because $\mathrm{p}$-value is greater than 0.05 (Table 6 ).

Table 5. One Way ANOVA for the differences in the means of the English language anxiety according to college level

\begin{tabular}{lccccc}
\hline Variation of Source & Sum of Squares & DF & Mean Square & F & Sig. \\
\hline Between groups & 1.71 & 4 & 0.43 & & \\
Within groups & 112.65 & 208 & 0.54 & 0.79 & 0.53 \\
Total & 114.36 & 212 & & & \\
\hline
\end{tabular}

Table 6. Means, standard deviation, and t-test for the differences in means of English language anxiety attributed to program type and graduation year

\begin{tabular}{lcccccc}
\hline Program type & $\mathrm{N}$ & mean & $\mathrm{SD}$ & $\mathrm{t}$-value & $\mathrm{df}$ & $\mathrm{Sig}$. \\
\hline Full time/ Morning Student & 189 & 2.13 & 0.73 & -0.976 & 211 & 0.330 \\
Part time/ Evening & 24 & 2.28 & 0.79 & & & \\
Graduation Year & $\mathrm{N}$ & mean & $\mathrm{SD}$ & $\mathrm{t}$-value & $\mathrm{df}$ & Sig. \\
2012 \& before & 104 & 2.14 & 0.75 & & & \\
After 2012 & 109 & 2.16 & 0.72 & -0.211 & 211 & 0.833 \\
\hline
\end{tabular}

RQ3: Why English Language Learners face difficulties when they are taught mathematics in English?

The significant differences in means of English language anxiety attributed to the number of completed Mathematics courses were investigated through means and standard deviations. There were noticeable differences in the means of the English language anxiety that were calculated according to completed mathematics courses (Table 7). Moreover, one-way ANOVA test was conducted to find out if these differences are significant. The results show that there were no significant differences at $(\alpha \leq 0.05)$ in the means of the English language anxiety according to completed mathematics courses with $\mathrm{F}=(0.72)$ at $(0.0 .05)$ level of significance. There is significant difference at $(\alpha=0.05)$ in means of English language anxiety attributed to instructor, because p-value less than $(0.05)$ in favour of native English speaker. 
Table 7. Means and standard deviations for the English language anxiety according to completed mathematics course

\begin{tabular}{lccc}
\hline Completed Mathematics Courses & $\mathrm{N}$ & Mean & $\mathrm{SD}$ \\
\hline 1 & 10 & 2.14 & 0.94 \\
2 & 16 & 2.11 & 0.74 \\
3 & 15 & 2.16 & 0.81 \\
4 & 2 & 1.85 & 0.75 \\
5 & 19 & 2.16 & 0.71 \\
6 & 26 & 2.10 & 0.74 \\
7 & 34 & 2.18 & 0.66 \\
8 & 33 & 2.08 & 0.74 \\
9 & 22 & 2.07 & 0.76 \\
10 & 36 & 2.29 & 0.76 \\
Total & 213 & 2.15 & 0.73 \\
\hline
\end{tabular}

Table 8. One Way ANOVA for the differences in the means of the English language anxiety according to completed mathematics course and instructor

\begin{tabular}{|c|c|c|c|c|c|c|}
\hline Variation of Source & Sum of Squares & \multicolumn{2}{|c|}{$\mathrm{DF}$} & Mean Square & $\mathrm{F}$ & Sig. \\
\hline Between groups & 1.292 & \multicolumn{2}{|c|}{9.000} & 0.144 & & \\
\hline Within groups & 113.073 & \multicolumn{2}{|c|}{203.000} & 0.557 & 0.258 & 0.985 \\
\hline Total & 114.365 & \multicolumn{2}{|c|}{212.000} & & & \\
\hline The instructor & $\mathrm{N}$ & mean & $\mathrm{SD}$ & t-value & $\mathrm{df}$ & Sig. \\
\hline Native English Speaker & 74 & 2.29 & 0.63 & \multirow{2}{*}{2.23} & \multirow{2}{*}{211} & \multirow{2}{*}{$0.027^{*}$} \\
\hline Non-native English Speaker & 139 & 2.07 & 0.77 & & & \\
\hline
\end{tabular}

The association between English language anxiety levels and English language learners' achievement in Mathematics was investigated through Pearson's correlation test. The results show that the correlation coefficient between English language anxiety levels and English language learners' achievement in mathematics was -0.23 , which reveals a weak negative relationship with statistical significance at 0.05 level (Table 9).

Table 9. Pearson's correlation test

\begin{tabular}{lcc}
\hline English language anxiety & & \\
\hline & "R" Correlation Variable & -0.23 \\
English language learners' achievement in mathematics & Significance & 0.001 \\
& Number & 213 \\
\hline
\end{tabular}

\section{Discussion}

Rutherford-Becker and Vanderwood (2009) investigated a relationship between literacy and mathematics skills and found association between mathematics skills and reading skills. Similarly, Woodrow (2006) has provided several classifications for anxiety, trait, state, and situation-specific anxiety. Trait anxiety is the state of feeling anxious within several situations and implies a general psychological state that is continuous. State anxiety refers to being anxious temporarily when confronting a certain situation. Whereas, situation specific anxiety reflects a trait that recurs in specific situations (Woodrow, 2006).

The anxiety in learning second language is often associated with those learning a second language in an environment where the second language is needed for daily communication (Pappamihiel, 2002; Woodrow, 2006). Relationship between foreign language anxiety and achievement in language courses is highly focused. A majority of those studies have found a positive correlation between English language abilities and mathematical abilities among students across different levels of learning (Rutherford-Becker \& Vanderwood, 2009; Grimm, 2008; Pimperton \& Nation, 2010). Sovik et al. (1999) has analysed the relationship between reading comprehension and problem-solving strategies used in word problems among 9-year-old children. There was no significant evidence that students good at both reading comprehension and mathematics emphasized more on deductive problem-solving strategies as compared to students in other groups, who were not good at either reading or 
mathematics. Moreover, IQ was a stronger predictor of arithmetic word problem solving as compared to reading comprehension (Sovik et al., 1999).

Achievement gaps between EFL/ESL students and native English-speaking students have been observed widely (Lopez, 2010). According to the results of NAEP, only 54\% of EFL/ESL students scored the required achievement level in mathematics; while, $83 \%$ of their native-English-speaking peers scored the required level in mathematics (Perie et al., 2005). Purpura et al. (2011) investigated whether early literacy skills uniquely predicted early numeracy skill development among 3-5 years old children. The study suggested a unique relation between early numeracy skills and print knowledge and vocabulary. Moreover, Grimm (2008) conducted longitudinal study to investigate relationship between reading and mathematics achievement on a much larger sample size of 46,373 participants. The results showed that early reading comprehension was associated with changes in the application and conceptual understanding of mathematics as opposed to performing mathematical operations. This finding suggested a link between the cognitive processing abilities required for reading and understanding mathematical problems.

The connection between literacy and mathematics skills was investigated by Rutherford-Becker and Vanderwood (2009), who found significant association between reading and mathematics skills. Pimperton and Nation (2010) designed a study to investigate this relationship among poor comprehends by ELLs to further emphasize the connection between linguistic abilities and mathematics achievement. The participants were poor at comprehension but did well in all other parts of literacy and reading. The findings of this study stated that poor comprehension skills among the students did not differ significantly from controls on the numerical operations tasks but performed at a significantly lower level on the mathematical reasoning test as compared to the control group (Pimperton \& Nation, 2010).

Similarly, the study conducted by Xu \& Yu (2018) showed that students' engagement in a classroom can be significantly increased by incorporating action research projects. Fraga-Viñas and Bobadilla-Pérez (2015) have asserted that the implementation of action research projects addresses challenging tasks and reduce the rates of academic failure of EFL students. Bubnys (2019) showed that self-reflection is likely to provide in-depth insights to the students about themselves and also improve their personal strengths. However, the present study has shown that English language anxiety levels were medium among majority of the students as they claimed that they become nervous, when the teacher asks them unexpected questions. A study conducted by Alrabai (2014) investigated the anxiety coping strategies and showed that the main sources of anxiety among the Saudi EFL learners were their negative attitude, negative evaluations, and communication apprehension. Halder (2018) explored the association between anxiety and academic achievement of the students. The results showed that the level of anxiety and academic achievement are negatively correlated.

\subsection{Conclusion}

The present study has investigated the relationship between English language anxiety and the mathematical achievement of students, who are English language learners. There is debilitating impact of anxiety on the students, who speak English. Therefore, it is important that instructors should be sensitive during classroom interactions and can be helpful to students to minimize the anxiety of learning in a foreign or second language. The study has concluded that the levels of English language anxiety levels were medium among majority of the students as they claimed that they become nervous, when the teacher asks them unexpected questions. It is important that instructors should be sensitive during classroom interactions that would help students to minimize their anxiety levels. Moreover, there were no significant differences in the means of English language anxiety according to completed mathematics courses. The study results are influential for the second language students, who have started their university courses to investigate contextual influences on second language speaking anxiety. The results of the study are limited as there are no statistics for some of the themes that were about interacting with an instructor. However, investigation on contextual influences on second language speaking anxiety would be beneficial to investigate the impact of courses on second language speaking anxiety.

\section{References}

Abedi, J., Courtney, M., Leon, S., Kao, J., \& Azzam, T. (2006). English Language Learners and Math Achievement: A Study of Opportunity to Learn and Language Accommodation. Technical Report 702. National Center for Research on Evaluation, Standards, and Student Testing (CRESST).

Alrabai, F. (2015). The influence of teachers' anxiety-reducing strategies on learners' foreign language anxiety. $\begin{aligned} & \text { Innovation in Language Learning and Teaching, } \\ & \text { https://doi.org/10.1080/17501229.2014.890203 }\end{aligned}$. 
Awan, R. U. N., Azher, M., Anwar, M. N., \& Naz, A. (2010). An investigation of Foreign Language anxiety and its relationship with students' achievement. Journal of College Teaching and Learning (TLC), 7(11). https://doi.org/10.19030/tlc.v7i11.249

Bailey, A. L., \& Heritage, M. (2014). The role of language learning progressions in improved instruction and assessment of English language learners. TESOL Quarterly, 48(3), 480-506. https://doi.org/10.1002/tesq.176

Bubnys, R. (2019). A Journey of Self-Reflection in Students' Perception of Practice and Roles in the Profession. Sustainability, 11(1), 194. https://doi.org/10.3390/su11010194

Chval, K. B., Pinnow, R. J., \& Thomas, A. (2015). Learning how to focus on language while teaching mathematics to English language learners: A case study of Courtney. Mathematics Education Research Journal, 27(1), 103-127. https://doi.org/10.1007/s13394-013-0101-8

Collins, K. T., Onwuegbuzie, A. J., \& Sutton, I. L. (2006). A model incorporating the rationale and purpose for conducting mixed-methods research in special education and beyond. Learning Disabilities- $A$ Contemporary Journal, 4(1), 67-100.

Cuevas, G. J. (1984). Mathematics learning in English as a second language. Journal for research in mathematics education, 134-144. https://doi.org/10.2307/748889

Edel, M. (2018). Performance in Math and Science by English Language Learners.

Ewald, J. D. (2007). Foreign Language Learning Anxiety in Upper-Level Classes: Involving Students as $\begin{array}{lllll}\text { Researchers. } & \text { Foreign } & \text { Language } & \text { Annals, } & \text { 40(1), }\end{array}$ https://doi.org/10.1111/j.1944-9720.2007.tb02857.x

Fraga-Viñas, L., \& Bobadilla-Pérez, M. (2015). Action research in the communicative language classroom: using alternative assessment techniques with efl secondary-school students. HUARTE DE SAN JUAN. Filología y Didáctica de la Lengua N. 15/Filologia eta Hizkuntzaren Didaktika 15 Z. Pamplona: Universidad Pública de Navarra/Nafarroako Unibertsitate Publikoa, 2015 (pp. 67-77).

Gai, F. P., \& Yang, D. (2010). A Study on College Students' Anxiety to Spoken English. Canadian Social Science, 6(2), 95.

Grimm, J. J. (2008). Longitudinal associations between reading and mathematics achievement. Developmental Neurophsychology, 33(4), 410-426. https://doi.org/10.1080/87565640801982486

Halder, D. U. K. (2018). English Language Anxiety and Academic Achievement.

Hong, E., Mason, E., Peng, Y., \& Lee, N. (2015). Effects of homework motivation and worry anxiety on homework achievement in mathematics and English. Educational Research and Evaluation, 21(7-8), 491-514. https://doi.org/10.1080/13803611.2015.1131721

Horwitz, E. K., Horwitz, M. B., \& Cope, J. (1986). Foreign Language anxiety. The modern language journal, 70(2), 125-132. https://doi.org/10.1111/j.1540-4781.1986.tb05256.x

Hung, H. T. (2015). Flipping the classroom for English language learners to foster active learning. Computer Assisted Language Learning, 28(1), 81-96. https://doi.org/10.1080/09588221.2014.967701

Hwang, G. J., Hsu, T. C., Lai, C. L., \& Hsueh, C. J. (2017). Interaction of problem-based gaming and learning anxiety in language students' English listening performance and progressive behavioral patterns. Computers \& Education, 106, 26-42. https://doi.org/10.1016/j.compedu.2016.11.010

Joen, J. (2002). Learners' evaluation on English-medium lectures. Foreign Language Education, 9(4), 233-251.

Kim, E. (2002). Voices of learners from English-medium lectures. The Korean Journal of Applied Linguistics, 18(2), 145-163.

Lee, M. L. (2011). 14 Differences in the Learning Anxieties Affecting College Freshman Students of EFL.

Liu, M. (2007). Chinese students' motivation to learn English at the tertiary level. Asian EFL Journal, 9(1), 126-146.

Lopez, O. S. (2010). The digital learning classroom: Improving English language learners' academic success in mathematics and reading using interactive whiteboard technology. Computers and Education, 54(4), 901-915. https://doi.org/10.1016/j.compedu.2009.09.019

MacIntyre, P. D. (1995). How does anxiety affect second language learning? A reply to Sparks and Ganschow. 
The Modern Language Journal, 79(1), 90-99. https://doi.org/10.1111/j.1540-4781.1995.tb05418.x

Mahmood, A., \& Iqbal, S. (2010). Difference of student anxiety level towards English as a foreign language subject and their academic achievement. International Journal of Academic Research, 2(6).

$\mathrm{Na}$, Z. (2007). A study of high school students' English learning anxiety. The Asian EFL Journal, 9(3), 22-34.

Otilia, C. (2014). Understanding English Language Learners' Needs in Mathematics Education. Journal of Education \& Human Development.

Pappamihiel, N. E. (2002). English as a second language students and English language anxiety: Issues in the mainstream classroom. Research in the Teaching of English, 327-355.

Perie, M., Grigg, W., \& Dion, G. (2005). The Nation's Report Card [TM]: Mathematics, 2005. NCES 2006-453. National Center for Education Statistics.

Pimperton, H., \& Nation, K. (2010). Understanding words, understanding numbers: an exploration of the mathematical profiles of poor comprehenders. British Journal of Educational Psychology, 80, 255-268. https://doi.org/10.1348/000709909X477251

Purpura, D. J., Hume, L. E., Sims, D. M., \& Lonigan, C. J. (2011). Early literacy and early numeracy: The value of including early literacy skills in the prediction of numeracy development. Journal of Experimental Child Psychology, 110, 647-658. https://doi.org/10.1016/j.jecp.2011.07.004

Rosa, M. (2015). A mixed-methods study to understand the perceptions of high school leaders about English language learners (ELLs): The case of mathematics. Jornal Internacional de Estudos em Educação Matemática, 4(2).

Rutherford-Becker, K. J., \& Vanderwood, M. L. (2009). Evaluation of the relationship between literacy and mathematics skills as assessed by curriculum-based measures. The California School Psychologist, 14, 23-34. https://doi.org/10.1007/BF03340948

Sovik, N., Frostrad, P., \& Heggberget, M. (1999). The relation between reading comprehension and task-specific strategies used in arithmetical word problems. Scandinavian Journal of Educational Research, 43(4), 371-398. https://doi.org/10.1080/0031383990430403

Woodrow, L. (2006). Anxiety and speaking English as a second language. RELC journal, 37(3), 308-328. Wu, K. H. (2010). The relationship between language learners' anxiety and learning strategy in the CLT classrooms. International Education Studies, 3(1), 174. https://doi.org/10.5539/ies.v3n1p174

Xu, Q., \& Yu, S. (2018). An Action Research on Computer-Mediated Communication (CMC) Peer Feedback in EFL Writing Context. The Asia-Pacific Education Researcher, 27(3), 207-216. https://doi.org/10.1007/s40299-018-0379-0

Yamashiro, A. D., \& McLaughlin, J. (2001). Relationships among attitudes, motivation, anxiety, and English language proficiency in Japanese college students. Second language research in Japan, 112-126.

\section{Copyrights}

Copyright for this article is retained by the author(s), with first publication rights granted to the journal.

This is an open-access article distributed under the terms and conditions of the Creative Commons Attribution license (http://creativecommons.org/licenses/by/4.0/). 